Bulgarian Journal of Veterinary Medicine, 2015, 18, No 4, 373-377

ISSN 1311-1477; DOI: 10.15547/bjvm.881

Short communication

\title{
ANTIMICROBIAL ACTIVITY OF ESSENTIAL OILS AND EXTRACTS FROM BLACK PEPPER, CUMIN, CORIANDER AND CARDAMOM AGAINST SOME PATHOGENIC AND SAPROPHYTIC MICROORGANISMS
}

\author{
D. TENEVA ${ }^{1}$, Z. DENKOVA ${ }^{1}$, R. DENKOVA ${ }^{2}$, T. ATANASOVA ${ }^{3}$, \\ N. NENOV ${ }^{4} \&$ P. MERDZHANOV ${ }^{3}$ \\ ${ }^{1}$ Department of Microbiology, ${ }^{2}$ Department of Biochemistry and Molecular \\ Biology, ${ }^{3}$ Department of Essential Oils, ${ }^{4}$ Department of Heating Technology, \\ University of Food Technologies, Plovdiv, Bulgaria
}

\section{Summary}

Teneva, D., Z. Denkova, R. Denkova, T. Atanasova, N. Nenov \& P. Merdzhanov, 2015. Antimicrobial activity of essential oils and extracts from black pepper, cumin, coriander and cardamom against some pathogenic and saprophytic microorganisms. Bulg. J. Vet. Med., 18, No 4, 373-377.

The antimicrobial activity of essential oils and extracts of fruits of black pepper (Piper nigrum L.), cumin (Cuminum cyminum L.), coriander (Coriandrum sativum L.) and cardamom (Elettaria cardamomum) against pathogenic (Escherichia coli ATCC 25922, Escherichia coli ATCC 8739, Salmonella sp. (clinical isolate), Staphylococcus aureus ATCC 6538P, Proteus vulgaris G) and saprophytic (Bacillus cereus ATCC 11778, Penicillium sp., Rhizopus sp., Aspergillus niger, Saccharomyces cerevisiae) microorganisms was examined by disc-diffusion and well-diffusion methods. The essential oils and the extracts inhibited the growth of pathogenic and saprophytic microorganisms causing gastrointestinal diseases. Gram-positive bacteria were more sensitive to the extracts and oils (inhibition zones between 9.5 and $20 \mathrm{~mm}$ ) and the minimum inhibitory concentration was more than $600 \mathrm{ppm}$. The tested Gram-negative bacteria were less sensitive (zones of inhibition between 8 and $12 \mathrm{~mm}$ ) with a minimum bactericidal concentration more than $600 \mathrm{ppm}$. The obtained essential oils and extracts are suitable for use as biopreservative agents.

Key words: antimicrobial activity, black pepper, cardamom, coriander, cumin, essential oil

Antimicrobial properties of the herbs are due to various chemical compounds including volatile oils, alkaloids and tannins that are presented in their tissue. Plant metabolites are a promising alternative to antifungal treatment and control because plants generate a wide variety of compounds, either as part of their development or in response to stress or pathogen attack (Bakkali et al., 2008; Rajkovic et al., 2015). Preliminary clinical trials have documented their therapeutic use for the 
treatment of variety of diseases and conditions that include diarrhoea, asthma, hypertension, diabetes, inflammation, cough, bronchitis, headache, eczema, fever, dizziness, influenza and dental caries (Gilani et al., 2001; Ali \& Blunden, 2003). Numerous studies have demonstrated the antimicrobial activity of essential oils and extracts obtained from the fruits of black pepper, cumin, coriander and cardamom (Hajlaoui et al., 2010). Essential oils are one of the most promising groups of natural compounds for the development of safer antifungal agents (Moghaddam et al., 2015). The pronounced antibacterial and antioxidant properties of oils and extracts turn them into natural preservatives, helping to increase the safety of food. They are also applied in perfumery and cosmetics industry and in medicine. The antimicrobial activity of spices and their effect in food products is determined by several factors: type, composition and quantity of spices; microbial species and the extent of contamination; composition of the medium; conditions of the technological process and storage of food products (Dobreva et al., 2009). As a result of the inherent secondary metabolism of plants a number of substances are synthesised: essential oils, alkaloids, flavonoids, tannins, glycosides and other compounds that explain the antimicrobial properties of the products, derived from them (Iacobellis et al., 2005; Souza et al., 2005).

The aim of the present research was to determine the antimicrobial activity of essential oils and extracts from fruits of black pepper, cumin, coriander and cardamom against pathogenic and saprophytic microorganisms for their application as natural preservatives that would improve food safety.
Essential oils were extracted by water distillation in a modification of a laboratory glass apparatus of the British Pharmacopoeia (Balinova \& Dyakov, 1974).

Minced spice fruits were processed at process parameters with respect to the ratio of material:water $=1: 20$; ratio raw material:volume of the flask $=1: 100,6 \%$ rate and duration of $300 \mathrm{~min}$. Distillation ended when two consecutive measurements within $30 \mathrm{~min}$ did not show an increase in the amount of essential oil. The extraction was carried out in the laboratory extractor with a volume of 1 $\mathrm{dm}^{3}$ with the following parameters: temperature $25-30{ }^{\circ} \mathrm{C}$, pressure $0.7-0.8$ $\mathrm{MPa}$ and continuous perculation for 30 min. Freon $134 \mathrm{a}(1,1,1,2$ tetrafluoroethane) was used as extragen, authorised for food. The solvent had the following indicators: relative density at $20^{\circ} \mathrm{C}$ and 100 $\mathrm{kHz}-1.013$, dipole moment - 2.060 Debay, polarisation $13.8 \mathrm{~cm}^{3} / \mathrm{mol}$, dynamic viscosity at $20{ }^{\circ} \mathrm{C}-198 \mu \mathrm{Pa} . \mathrm{s}$, surface tension at $20{ }^{\circ} \mathrm{C}-8 \mathrm{mN} / \mathrm{m}$ (Georgiev \& Stoyanova, 1997).

Test microorganisms for determining the antimicrobial activity were as followed: Escherichia coli ATCC 25922, Escherichia coli ATCC 8739, Salmonella sp. (clinical isolate), Staphylococcus aureus ATCC 6538P, Proteus vulgaris G, Bacillus cereus ATCC 11778, Penicillium sp., Rhizopus sp., Aspergillus niger, Saccharomyces cerevisiae. All strains have been deposited in the culture collection of the Department of Microbiology at University of Food Technology, Plovdiv.

The antimicrobial activity was studied by two methods:

1) Agar disc diffusion method using $6 \mathrm{~mm}$ paper discs and pipetting $6 \mu \mathrm{L}$ of the sample; 
2) Agar serial tube dilution method with results expressed as minimum inhibitory concentration (MIC).

The essential oils or extracts were diluted and the experiments were conducted with dilutions $1 \times, 10 \times$ and
$100 \times$ in order to determine the MIC. Paper discs soaked in distilled water were used as controls. The results were recorded as diameters of the clear zones around the paper discs, in millimeters, after 24 48 hours of incubation of the Petri dishes

Table 1. Antimicrobial activity of extracts from fruits of black pepper, cumin, coriander and cardamom

\begin{tabular}{|c|c|c|c|c|c|c|c|c|}
\hline \multirow{2}{*}{$\begin{array}{l}\text { Spices } \\
\text { Test-micro- } \\
\text { organisms }\end{array}$} & \multicolumn{2}{|c|}{ Black pepper } & \multicolumn{2}{|c|}{ Cumin } & \multicolumn{2}{|c|}{ Coriander } & \multicolumn{2}{|c|}{ Cardamom } \\
\hline & $\begin{array}{l}\mathrm{IZ} \\
\mathrm{mm}\end{array}$ & $\begin{array}{l}\mathrm{MIC}, \\
\mathrm{ppm}\end{array}$ & $\begin{array}{l}\mathrm{IZ} \\
\mathrm{mm}\end{array}$ & $\begin{array}{l}\mathrm{MIC}, \\
\mathrm{ppm}\end{array}$ & $\begin{array}{l}\mathrm{IZ} \\
\mathrm{mm}\end{array}$ & $\begin{array}{l}\mathrm{MIC}, \\
\mathrm{ppm}\end{array}$ & $\begin{array}{l}\mathrm{IZ} \\
\mathrm{mm}\end{array}$ & $\begin{array}{l}\mathrm{MIC}, \\
\mathrm{ppm}\end{array}$ \\
\hline $\begin{array}{l}\text { Bacillus cereus } \\
\text { ATCC } 11778\end{array}$ & $10 \pm 0.48$ & 60 & $12 \pm 0.47$ & $>600$ & $10 \pm 0.48$ & 60 & $18 \pm 0.47$ & $>600$ \\
\hline Penicillium sp. & $9 \pm 0.47$ & $>600$ & $9.5 \pm 0.4$ & 60 & $9.5 \pm 0.4$ & 60 & $8 \pm 0.47$ & 600 \\
\hline Rhizopus sp. & $8 \pm 0.47$ & 600 & $8 \pm 0.47$ & 600 & $9 \pm 0.47$ & 60 & $8 \pm 0.47$ & 600 \\
\hline Aspergillus niger & $8.5 \pm 0.4$ & $>600$ & $10 \pm 0.47$ & 60 & $8 \pm 0.47$ & 60 & $8 \pm 0.47$ & 60 \\
\hline $\begin{array}{l}\text { Saccharomyces } \\
\text { cerevisiae }\end{array}$ & $9.5 \pm 0.4$ & 60 & $9 \pm 0.47$ & 60 & $9 \pm 0.47$ & 6 & $8 \pm 0.47$ & 600 \\
\hline $\begin{array}{l}\text { Staph. aureus } \\
\text { ATCC } 6538\end{array}$ & - & - & $8 \pm 0.47$ & 600 & $9 \pm 0.4$ & $>600$ & $9 \pm 0.47$ & $>600$ \\
\hline Proteus vulgaris $\mathrm{G}$ & - & - & $9.5 \pm 0.4$ & 60 & $9 \pm 0.47$ & 60 & $9 \pm 0.48$ & 6 \\
\hline Salmonella sp. & - & - & $8 \pm 0.47$ & 600 & $8 \pm 0.48$ & 600 & $9 \pm 0.40$ & 6 \\
\hline E. coli ATCC 8739 & $9 \pm 0.48$ & 6 & $9.5 \pm 0.48$ & 60 & $10 \pm 0.47$ & 60 & $9 \pm 0.48$ & 6 \\
\hline $\begin{array}{l}\text { E. coli ATCC } \\
25922\end{array}$ & - & - & $9.5 \pm 0.47$ & 60 & $8.5 \pm 0.65$ & 60 & $9 \pm 0.47$ & 6 \\
\hline
\end{tabular}

Table 2. Antimicrobial activity of oils from fruits of black pepper, cumin, coriander and cardamom

\begin{tabular}{|c|c|c|c|c|c|c|c|c|}
\hline \multirow{2}{*}{$\begin{array}{l}\text { Spices } \\
\text { Test-micro- } \\
\text { organisms }\end{array}$} & \multicolumn{2}{|c|}{ Black pepper } & \multicolumn{2}{|c|}{ Cumin } & \multicolumn{2}{|c|}{ Coriander } & \multicolumn{2}{|c|}{ Cardamom } \\
\hline & $\mathrm{IZ}, \mathrm{mm}$ & $\begin{array}{l}\text { MIC, } \\
\text { ppm }\end{array}$ & $\begin{array}{l}\mathrm{IZ}, \\
\mathrm{mm}\end{array}$ & $\begin{array}{l}\text { MIC, } \\
\text { ppm }\end{array}$ & $\begin{array}{l}\mathrm{IZ}, \\
\mathrm{mm}\end{array}$ & $\begin{array}{l}\mathrm{MIC}, \\
\mathrm{ppm}\end{array}$ & $\begin{array}{l}\mathrm{IZ} \\
\mathrm{mm}\end{array}$ & $\begin{array}{l}\mathrm{MIC}, \\
\mathrm{ppm}\end{array}$ \\
\hline $\begin{array}{l}\text { Bacillus cereus } \\
\text { ATCC } 11778\end{array}$ & $9.5 \pm 0.48$ & 60 & $11 \pm 0.47$ & $>600$ & $9 \pm 0.45$ & $>600$ & $9.5 \pm 0.47$ & $>600$ \\
\hline Penicillium sp. & $8 \pm 0.4$ & 600 & $25 \pm 0.81$ & $>600$ & $8 \pm 0.40$ & 60 & $10 \pm 0.4$ & 60 \\
\hline Rhizopus sp. & $9 \pm 0.47$ & 6 & $8 \pm 0.47$ & 600 & $9 \pm 0.48$ & 60 & $8 \pm 0.47$ & 600 \\
\hline Aspergillus niger & $9 \pm 0.48$ & 60 & $25 \pm 0.94$ & $>600$ & $8 \pm 0.47$ & 6 & $8 \pm 0.4$ & 600 \\
\hline $\begin{array}{l}\text { Saccharomyces } \\
\text { cerevisiae }\end{array}$ & $9 \pm 0.47$ & 60 & $9 \pm 0.47$ & 60 & $8 \pm 0.47$ & 600 & $9 \pm 0.48$ & 60 \\
\hline $\begin{array}{l}\text { Staph. aureus } \\
\text { ATCC } 6538\end{array}$ & $10 \pm 0.47$ & 6 & $20 \pm 0.94$ & $>60$ & $10 \pm 0.48$ & 60 & $10 \pm 0.48$ & 60 \\
\hline Proteus vulgaris $\mathrm{G}$ & $9 \pm 0.47$ & 6 & $8 \pm 0.47$ & 600 & $8 \pm 0.47$ & 600 & $9 \pm 0.48$ & 60 \\
\hline Salmonella sp. & $9 \pm 0.48$ & 6 & $9 \pm 0.48$ & $>600$ & $8 \pm 0.4$ & 600 & $12 \pm 0.4$ & 6 \\
\hline E. coli ATCC 8739 & $9 \pm 0.47$ & 6 & $9 \pm 0.48$ & 60 & $8 \pm 0.47$ & 600 & $8 \pm 0.47$ & 600 \\
\hline $\begin{array}{l}\text { E. coli ATCC } \\
25922\end{array}$ & $9 \pm 0.48$ & 6 & $8 \pm 0.4$ & 600 & $8 \pm 0.4$ & 600 & $8 \pm 0.47$ & 600 \\
\hline
\end{tabular}


at optimal temperature for the growth of the corresponding test-microorganism (at $30{ }^{\circ} \mathrm{C}$ for the saprophytic microorganisms and at $37^{\circ} \mathrm{C}$ for the pathogenic microorganisms) (Jirovetz et al., 2006). The MIC was defined as the lowest concentration of the essential oil at which the microorganism does not demonstrate visible growth (Randrianarivelo et al., 2009).

The experiments were performed in quadruplicate. The mean values and the standard deviations were calculated using MS Office Excel 2010. The MICs, in ppm, were calculated on the basis of the obtained results.

The essential oils and the extracts of black pepper, cumin, coriander and cardamom inhibited the growth of pathogenic and saprophytic microorganisms causing gastrointestinal diseases. The method used to assess the antimicrobial activity, and the choice of the test microorganisms vary between publications. The permeability of the bacterial membranes, the presence of porin proteins in Gram-negative bacteria and the intracellular distribution of the oil constituents are key elements that influence the diffusion and the action of the essential oil into the cell. In most literature reports, Gram-positive organisms appear to be more sensitive than Gramnegative to essential oils. However, other studies do not confirm this observation, as Gram-positive bacteria have been found to be less or equally sensitive to Gramnegative bacteria as well (Burt, 2004; Randrianarivelo et al., 2009).

In the present study Gram-positive bacteria were more sensitive to the extracts and oils (inhibition zones between 9.5 and $20 \mathrm{~mm}$ ) and the minimum inhibitory concentration was more than 600 ppm. The tested Gram-negative bacteria were less sensitive (zones of inhibition between 8 and $12 \mathrm{~mm}$ ) with the minimum bactericidal concentration exceeded 600 ppm (Tables 1 and 2). This was due to the difference in the structure and composition of the cell walls of the two groups of bacteria. The presence of an outer membrane in Gram-negative bacteria hindered the diffusion of the extracts through the membrane to the protoplasm of the cell, making them more stable under the effect of the tested extracts. The black pepper oil demonstrated antimicrobial activity against all tested test microorganisms as compared to the extract. This was due to the difference in the chemical composition of the oil and the extract. Strong antimicrobial activity against fungi and yeasts was observed: the respective inhibition zones attained up to $25 \mathrm{~mm}$, and the MIC was more than $600 \mathrm{ppm}$.

\section{REFERENCES}

Ali, B. H. \& G. Blunden, 2003. Pharmacological and toxicological properties of Nigella sativa. Phytotherapy Research, 17, 299-305.

Bakkali, F., S. Averbeck, D. Averbeck \& M. Idaomar, 2008. Biological effects of essential oils - a review. Food and Chemical Toxicology, 46, 446-475.

Balinova, A. \& G. Dyakov, 1974. Improved apparatus for microdestilation of rose flower. Agricultural Science (Sofia), 11, 79-85 (BG).

Burt, S., 2004. Essential oils: Their antibacterial properties and potential applications in foods - a review. International Journal of Food Microbiology, 94, 223-253.

Dobreva, K., S. Boicheva, V. Gochev \& A. Stoyanova, 2009. Antimicrobial activity of extracts from spice mixtures. Trakia Journal of Sciences, 7, 191-195.

Georgiev, E. \& A. Stoyanova, 1997. Laboratory Manual on Technology of Essential Oils and Aromatic Compounds, Plovdiv, 1997. 
Gilani, A., N. Aziz, I. Khurram, K. Chaudhary \& A. Iqbal, 2001. Bronchodilator, spasmolytic and calcium antagonist activities of Nigella sativa seeds (Kalonji): A traditional herbal product with multiple medicinal uses. Journal of Pakistan Medical Association, 51, 115-120.

Hajlaoui, H., H. Mighri, E. Noumi, M. Snoussi, N. Trabelsi \& R. Ksouri, 2010. Chemical composition and biological activities of Tunisian Cuminum cyminum $\mathrm{L}$. essential oil: A high effectiveness against Vibrio spp. strains. Food and Chemical Toxicology, 48, 2186-2192.

Iacobellis, N., P. Cantore, F. Capasso \& F. Senatore, 2005. Antibacterial activity of Cuminum cyminum L. and Carum carvi L. essential oils. Journal of Agricultural and Food Chemistry, 53, 57-61.

Jirovetz, L., G. Buchbauer, Z. Denkova, A. Slavchev, A. Stoyanova \& E. Schmidt, 2006. Chemical composition, antimicrobial activities and odor descriptions of various Salvia sp. and Thuja sp. essential oils. Ernahrung / Nutrition, 30, 152-159.

Moghaddam, M., P. Taheri, A. G. Pirbalouti \& L. Mehdizadeh, 2015. Chemical composition and antifungal activity of essential oil from the seed of Echinophora platyloba DC. against phytopathogens fungi by two different screening methods. $L W T$ - Food Science and Technology, 61, 536542.
Rajkovic, K., M. Pekmezovic, A. Barac, J. Nikodinovic-Runic \& V. A. Arsenijevic, 2015. Inhibitory effect of thyme and cinnamon essential oils on Aspergillus flavus: Optimization and activity prediction model development. Industrial Crops and Products, 65, 7-13.

Randrianarivelo, R., S. Sarter, E. Odoux, P. Brat, M. Lebrun, B. Romestand, C. Menut, H. S. Andrianoelisoa, M. Raherimandimby \& P. Danthu, 2009. Composition and antimicrobial activity of essential oils of $\mathrm{Cin}$ namosma fragrans. Food Chemistry, 114, 680-684.

Souza, E., T. Stamford, E. Lima, V. Trajano \& J. Filho, 2005. Antimicrobial effectiveness of spices: An approach for use in food conservation systems. Brazilian Archives of Biology and Technology, 48, 549-558.

Paper received 24.11.2014; accepted for publication 22.01.2015

\section{Correspondence:}

Desislava Teneva

Department of Microbiology, University of Food Technologies 26 Maritsa blvd, 4002 Plovdiv, Bulgaria e-mail: desi_gerinska@yahoo.com 